\title{
Ready-to-eat food consumption practices, food safety knowledge and relation to gender and education level of consumers in Kuala Lumpur, Malaysia
}

\author{
${ }^{1}$ Anusha, A.C.S., ${ }^{2, *}$ Tunung, R., ${ }^{1}$ Kavita, C., ${ }^{2}$ Ribka, A. and ${ }^{3}$ Chandrika, M. \\ ${ }^{I}$ Faculty of Applied Sciences, UCSI University Kuala Lumpur Campus, Taman Connaught, Cheras 56000 \\ Kuala Lumpur, Malaysia \\ ${ }^{2}$ Faculty of Agriculture and Food Sciences, Universiti Putra Malaysia Bintulu Sarawak Campus, Nyabau \\ Road, 97008 Bintulu, Sarawak, Malaysia \\ ${ }^{3}$ Faculty of Medicine and Health Sciences, University Malaysia Sabah, Jalan UMS, 88400 Kota Kinabalu, \\ Sabah, Malaysia
}

\author{
Article history: \\ Received: 25 January 2020 \\ Received in revised form: 2 \\ April 2020 \\ Accepted: 8 April 2020 \\ Available Online: 25 April \\ 2020
}

\section{Keywords:}

Ready-to-eat,

Consumer,

Consumption practice,

Food safety knowledge

DOI:

https://doi.org/10.26656/fr.2017.4(5).037

\begin{abstract}
This study was aimed to evaluate consumers' consumption practices of ready-to-eat (RTE) foods, food safety knowledge, and the relationship to gender and education level. A total of 258 consumers in Klang Valley, Kuala Lumpur, Malaysia were given questionnaires through convenience sampling. The results showed that the biggest motivation for consumers in purchasing RTE foods was convenience (47.3\%). 40.7\% of respondents purchase RTE foods more than twice a week, and $36.8 \%$ of respondents consumed RTE food at restaurants and cafes. A total of $54.3 \%$ of the respondents purchased RTE foods for lunch, and 48.1\% of respondents usually spend RM11-RM20 per person. About $81 \%$ of respondents knew that the common symptom of foodborne disease is diarrhea, and $42.2 \%$ of respondents knew about the correct temperature for refrigeration. Most of the respondents (66.7\%) knew that room temperature encourages the multiplication of bacteria, and $36.4 \%$ of respondents knew that bacteria will grow quickly at body temperature. About $60.9 \%$ of respondents knew that raw and cooked food should be separated to prevent the transfer of bacteria, and $62 \%$ of the respondents knew that placing raw meat in the plastic bag before putting it into the grocery basket decreases the chance of foodborne illness. However, only $10.1 \%$ of the respondents knew that the best way to clean a cutting board after using it for raw meat is by washing with bleach and water. Female respondents and those with higher education level generally had better food safety knowledge. This study could benefit RTE food marketers in gaining better insights into consumers' behavior patterns towards RTE food. This study could also contribute to knowing the baseline knowledge of consumers in food safety as it is essential for the development of effective health educational programmes.
\end{abstract}

\section{Introduction}

Worldwide, there is a growing demand for ready-toeat (RTE) food (Priyadarshini, 2015). RTE food is food that is offered without additional cooking or preparation, which is packed at the premises where they are being sold or are ready for consumption (Heroux et al., 2012; Priyadarshini, 2015). In Malaysia, the market of RTE food is increasing and has contributed significantly to the gross domestic product in Malaysia's food industry (Baskaran et al., 2017). Determining consumer preferences towards food-related behaviours and convenience as a food attribute is as important as the taste, health and price (Candel, 2001). Changes in lifestyle were considered as one of the major factors in purchasing RTE food, as well as the demand for convenience and hygienic food products (Priyadarshini, 2015). The development, maintenance and change of dietary patterns could be influenced by a variety of social, cultural and economic factors (Fotopoulos et al., 2009). Factors such as employment status, income level, perceived time pressure, convenience orientation and food-related lifestyle may as well influence the purchase motivation of RTE meals (Geeroms et al., 2007).

Due to the growing economic importance of the RTE 
food market, marketers require a better understanding of the factors that motivate a consumer's ready meal consumption (Olsen et al., 2010). It is important to understand consumer decision-making in order for companies and marketers to come up with suitable marketing strategies (Bae et al., 2010; Muniady et al., 2014). In Malaysia, there is still a lack of research carried out to understand consumer behaviours better (Muniady et al., 2014). Therefore this study intends to examine consumer consumption practices of RTE food in Malaysia.

However, the consumption of food prepared outside the home increases exposure to the risks posed by poor hygiene in food service (Feltes et al., 2017). Annually in the U.S., foodborne diseases cause approximately 48 million illnesses, 128000 hospitalisations, and 3000 deaths (FDA, 2017). World Health Organisation (WHO) reported that every year 220 million children contract diarrheal disease, and 96000 dies (WHO, 2019). To protect consumer health, FDA has established public health interventions such as demonstration of knowledge, controlling hands as a vehicle of contamination, time and temperature parameters for controlling pathogens, and the consumer advisory (USFDA, 2017). WHO has also been actively promoting safe food handling through systematic disease prevention and awareness programmes (WHO, 2019).

It is important to improve consumers' food safety knowledge and practice, as consumers have a pivotal role in preventing foodborne disease (Kennedy et al., 2005). It is therefore important to understand the baseline of consumers' food safety knowledge to facilitate the development of effective health education programmes in Malaysia. Most previous studies on food safety knowledge in Malaysia have mainly focused on specific groups, namely youths and local food handlers (Woh et al., 2016), hence this study aims to investigate the food safety knowledge of the general consumers in Klang Valley, Kuala Lumpur, Malaysia. The overall objectives of this study are to assess consumers' consumption practices of RTE foods, their food safety knowledge and the relationship to gender and education level.

\section{Materials and methods}

The survey instrument was developed based on previous studies (Bae et al., 2010; Carbas et al., 2013; Maysenburg et al., 2014). The questionnaire consisted of three parts to assess the demographic profile of the respondents, the consumption practices of RTE foods including factors that motivated consumers to purchase RTE foods, and food safety knowledge among consumers.

A pilot test was performed with 45 consumers who purchased RTE meals. Based on the results, the questionnaire was modified for the demographic section. The finalized questionnaire was distributed to 320 respondents (after sample size calculation) by convenience sampling at shopping malls in Ampang and Kepong area in Klang Valley, Kuala Lumpur, Malaysia, and was collected over 3 months. Out of the 320, 300 questionnaires were collected, resulting in a response rate of $93.8 \%$. After deleting incomplete responses, 258 responses were finally applied for data analysis.

Data were analyzed using IBM SPSS Statistics 21 by performing descriptive analysis and Chi-square tests. Ethical approval for this study was obtained from UCSI University Ethics Committee. Both informed and written consents were sought from all participants. The assurance of anonymity and confidentiality was maintained throughout the study.

\section{Results and discussion}

The purpose of this study was to assess consumers' consumption practices of RTE food, their food safety knowledge, and the relationship to gender and education status. The results of this study could help RTE food marketers gain better insights into consumers' attitude and behavior patterns towards RTE food (Bae et al., 2010).

The demographic characteristics of the 258 respondents were presented in Table $1.61 .2 \%$ of the respondents were female and $38.8 \%$ were male, mostly aged $20-30$ years old $(53.5 \%)$, followed by $31-40$ years old $(30.6 \%), 41-50$ years old $(10.5 \%)$, and $>50$ years old (5.4\%). Majority respondents received tertiary education with $41.9 \%$ Degree holders and $13.6 \%$ postgraduate level. The rest were Diploma level (22.5\%), SPM $(20.2 \%)$ and others (1.9\%). 55\% of the respondents were Malays, and up to $60.5 \%$, respondents were single. A majority received income of less than RM10 000 per year and worked for more than 5 years.

The consumers' consumption practices of RTE foods were presented in Table 2. According to the survey results, the biggest motivator for RTE foods was convenience $(47.3 \%)$. This is similar to the findings by Chae et al. (2008) targeting university students and from another study by Bae et al. (2010) targeting consumers in Korea. Brunner et al. (2010) also stated that convenience is one of the big trends in the food business. Convenience involves more than just saving time as it also includes minimizing physical and mental effort associated with planning and preparing meals. In this 
Table 1. Demographic characteristics of the respondents $(\mathrm{n}=258)$

\begin{tabular}{|c|c|c|}
\hline \multicolumn{2}{|c|}{ Profile Respondents } & Frequency $(\%)$ \\
\hline \multirow{2}{*}{ Gender } & Male & $100(38.8)$ \\
\hline & Female & $158(61.2)$ \\
\hline \multirow{4}{*}{ Age } & 20-30 years old & $138(53.5)$ \\
\hline & $31-40$ years old & $79(30.6)$ \\
\hline & $41-50$ years old & $27(10.5)$ \\
\hline & $>50$ years old & $14(5.4)$ \\
\hline \multirow{4}{*}{ Race } & Malay & $142(55)$ \\
\hline & Chinese & $61(23.6)$ \\
\hline & Indian & $42(16.3)$ \\
\hline & Others & $13(5.0)$ \\
\hline \multirow{3}{*}{ Marital Status } & Single & $156(60.5)$ \\
\hline & Married & $96(37.2)$ \\
\hline & Others & $6(2.3)$ \\
\hline \multirow{5}{*}{$\begin{array}{l}\text { Highest } \\
\text { Education Level }\end{array}$} & SPM or equivalent & $52(20.2)$ \\
\hline & Diploma or equivalent & $58(22.5)$ \\
\hline & Degree or equivalent & $108(41.9)$ \\
\hline & Postgraduate or equivalent & $35(13.6)$ \\
\hline & Others & $5(1.9)$ \\
\hline \multirow{4}{*}{ Income per year } & $<\mathrm{RM} 10000$ & $94(36.4)$ \\
\hline & RM11 000 - RM20 000 & $61(23.6)$ \\
\hline & RM21 $000-$ RM30 000 & $53(20.5)$ \\
\hline & $>$ RM30 000 & $50(19.4)$ \\
\hline \multirow{4}{*}{ Working Period } & None & $22(8.5)$ \\
\hline & Less than a year & $43(16.7)$ \\
\hline & $1-5$ years & $80(31.0)$ \\
\hline & More than 5 years & $113(43.8)$ \\
\hline
\end{tabular}

study, other factors for respondents to buy RTE foods are to try out different types of food $(22.1 \%)$, because home cooking is difficult (17.1\%), and due to its cheap price $(13.6 \%)$.

For the expenses of purchasing RTE food, the average expenses per person for a single purchase of an RTE food was between RM11 - RM20 (48.1\%), and only $38.8 \%$ respondents spent less than RM10. This interestingly shows that the respondents are willing to pay extra for the convenience they seek, even though most of the respondents $(36.4 \%)$ received income of less than RM10 000 per year. This is similar to the study by Brunner et al. (2010), which stated that convenience shoppers were less price-sensitive.

Most respondents (40.7\%) consume RTE foods more than twice a week, and up to $36.8 \%$, respondents purchased RTE food at restaurants and cafes. Besides that, a majority $(54.3 \%)$ of the respondents purchased RTE foods for their lunch. This shows that most of the respondents purchased RTE foods for full meals. This is in concordance to findings by Bae et al. (2010) who reported that consumers purchased RTE foods for full
Table 2. Consumers' RTE food consumption practices $(\mathrm{n}=258)$

\begin{tabular}{|c|c|c|}
\hline Item & Level & $\mathrm{n}(\%)$ \\
\hline \multirow{4}{*}{$\begin{array}{l}\text { Which factor } \\
\text { motivates you to } \\
\text { buy RTE food? }\end{array}$} & Convenience & $122(47.3)$ \\
\hline & $\begin{array}{l}\text { To try out different types of } \\
\text { food }\end{array}$ & $57(22.1)$ \\
\hline & Home cooking is difficult & $44(17.1)$ \\
\hline & Cheap price & $35(13.6)$ \\
\hline \multirow{4}{*}{$\begin{array}{l}\text { How frequently } \\
\text { do you consume } \\
\text { RTE food? }\end{array}$} & Once a month & $41(15.9)$ \\
\hline & Once a week & $45(17.4)$ \\
\hline & Twice a week & $67(26.0)$ \\
\hline & More than above & $105(40.7)$ \\
\hline \multirow{4}{*}{$\begin{array}{l}\text { Where do you } \\
\text { usually purchase } \\
\text { your RTE food? }\end{array}$} & Restaurants and cafes & $95(36.8)$ \\
\hline & Supermarkets or discount marts & $69(26.7)$ \\
\hline & Food courts & $60(23.3)$ \\
\hline & Convenience stores & $34(13.2)$ \\
\hline \multirow{5}{*}{$\begin{array}{l}\text { What is the } \\
\text { expenditure of } \\
\text { purchasing RTE } \\
\text { food per person? }\end{array}$} & $<\mathrm{RM} 10$ & $100(38.8)$ \\
\hline & RM11-RM20 & $124(48.1)$ \\
\hline & RM21-RM30 & $27(10.5)$ \\
\hline & RM31-RM40 & $0(0.0)$ \\
\hline & $>$ RM40 & $7(2.7)$ \\
\hline \multirow{4}{*}{$\begin{array}{l}\text { Which mealtime } \\
\text { do you purchase } \\
\text { RTE food? }\end{array}$} & Breakfast & $40(15.5)$ \\
\hline & Lunch & $140(54.3)$ \\
\hline & Dinner & $48(18.6)$ \\
\hline & Between meals & $30(11.6)$ \\
\hline \multirow{4}{*}{$\begin{array}{l}\text { Where do you get } \\
\text { sources of } \\
\text { purchasing } \\
\text { information? }\end{array}$} & $\begin{array}{l}\text { Direct recommendation (family, } \\
\text { friends, etc.) }\end{array}$ & $103(39.9)$ \\
\hline & $\begin{array}{l}\text { Comparison between } \\
\text { purchasing places }\end{array}$ & $70(27.1)$ \\
\hline & Advertising media & $52(20.2)$ \\
\hline & Others & $33(12.8)$ \\
\hline
\end{tabular}

meals. However, it is worthy to note that this study did not highlight whether the respondents consumed full meals or meal components in the survey forms. Hence, further research is needed in order to have a general idea of consumers' consumption practices of full meals and meal components (Scholliers, 2015). In this study, the rest of the respondents usually purchase RTE foods during dinner (18.6\%), breakfast (15.5\%) and in between meals $(11.6 \%)$. Other common venues to purchase RTE foods were supermarkets or discount marts $(26.7 \%)$, food courts (23.3\%) and convenience stores (13.2\%).

The findings in this study show that the most common source of purchasing information was a direct recommendation from family, friends and others $(39.9 \%)$. Only $27.1 \%$ of respondents stated that comparing prices between purchasing places was their source of purchasing information. Another study by Bae et al. (2010) also stated that the most common source of purchasing information was direct comparison at the place of purchase. About $20.2 \%$ of respondents stated that advertising media was their source of purchasing information. RTE food marketers would find these 
findings valuable since they could link their marketing strategy with consumers' perception and attitudes towards RTE meals.

Table 3 presents the consumers' food safety knowledge. Generally, most of the respondents had good food safety knowledge. A majority of the consumers $(42.2 \%)$ knew that the temperature in the refrigerator should be at $2-8^{\circ} \mathrm{C}$ and our findings are similar to the study by Garayoa et al. (2005) which stated that a majority $(71.5 \%)$ of their students knew the correct temperature values for refrigeration. In this current study, most respondents (36.4\%) knew that bacteria will grow quickly at the body's temperature $37^{\circ} \mathrm{C}$, and $66.7 \%$ knew that room temperature encourages the multiplication of bacteria. With regards to crosscontamination issues, $60.9 \%$ knew that raw and cooked food should be separated to prevent the transfer of bacteria, and $62 \%$ respondents also knew that placing raw meat in the plastic bag before putting it in the grocery basket decreases the chance of foodborne illness. A majority $(81 \%)$ knew that the common symptom of foodborne illness is diarrhea. This shows that the respondents had adequate food safety knowledge. This is most possibly due to the fact that most of the respondents were of Degree level and were somehow exposed to the basic food safety knowledge. This was also similar to the study by Garayoa et al. (2005) which reported that higher education level students had better food safety knowledge.

However, not many respondents knew that the best way to clean a cutting board after using it for raw meat is by washing with bleach and water (10.1\%). Most respondents (59.7\%) answered washing with soap water is the best way, $24.8 \%$ of respondents answered rinsing well with water, and $5.4 \%$ stated wiping it out with a dishrag. According to Garayoa et al. (2005), crosscontamination is a well-recognized factor in foodborne illness outbreaks. Factors such as contact between raw products and cooked meals inside the refrigerator and use of the same tool for different food handling tasks without proper washing are an important risk factor for cross-contamination.

A Chi-square test for independence indicated no significant differences between gender and the food poisoning knowledge $(p>0.05)$ except for the last question which had a significant difference with gender $(p<0.05)$. Based on Table 4, female respondents had better food poisoning knowledge compared to male respondents. Studies had shown the women have a

Table 3. Consumers' food safety knowledge $(n=258)$

\begin{tabular}{|c|c|c|}
\hline Item Level & & $\mathrm{n}(\%)$ \\
\hline \multirow{4}{*}{$\begin{array}{l}\text { Temperature in the refrigerator } \\
\text { should be at or below }\end{array}$} & $10^{\circ} \mathrm{C}$ & $19(7.4)$ \\
\hline & $* 2^{\circ} \mathrm{C}-8^{\circ} \mathrm{C}$ & $109(42.2)$ \\
\hline & $-18^{\circ} \mathrm{C}$ & $77(29.8)$ \\
\hline & I don't know & $53(20.5)$ \\
\hline \multirow{4}{*}{$\begin{array}{l}\text { At one's body temperature } \\
\left(37^{\circ} \mathrm{C}\right) \text {, what will happen to food } \\
\text { bacteria? }\end{array}$} & Die & $31(12.0)$ \\
\hline & No growth & $86(33.3)$ \\
\hline & *Grow quickly & $94(36.4)$ \\
\hline & Grow slowly & $47(18.2)$ \\
\hline \multirow{4}{*}{$\begin{array}{l}\text { Which factor encourages } \\
\text { multiplication of bacteria? }\end{array}$} & Refrigeration & $29(11.2)$ \\
\hline & *Room temperature & $172(66.7)$ \\
\hline & Sterilization and pasteurization & $25(9.7)$ \\
\hline & I don't know & $32(12.4)$ \\
\hline \multirow{4}{*}{$\begin{array}{l}\text { Why should you separate raw } \\
\text { and cooked food? }\end{array}$} & There will spoilage of food & $57(22.1)$ \\
\hline & The flavour will be affected & $32(12.4)$ \\
\hline & *Bacteria will transfer from raw to cooked food & $157(60.9)$ \\
\hline & I don't know & $12(4.7)$ \\
\hline \multirow{3}{*}{$\begin{array}{l}\text { Placing raw meat in the plastic } \\
\text { bag before putting it into the } \\
\text { grocery basket }\end{array}$} & Increases your chance of foodborne illness & $47(18.2)$ \\
\hline & *Decreases your chance of foodborne illness & $160(62.0)$ \\
\hline & Makes no difference in foodborne illness & $51(19.8)$ \\
\hline \multirow{4}{*}{$\begin{array}{l}\text { Which one is the common } \\
\text { symptom of foodborne illness? }\end{array}$} & Headache & $20(7.8)$ \\
\hline & *Diarrhea & $209(81.0)$ \\
\hline & Skin rashes & $16(6.2)$ \\
\hline & I don't know & $13(5.0)$ \\
\hline \multirow{4}{*}{$\begin{array}{l}\text { What is the best way to clean a } \\
\text { cutting board after it is used for } \\
\text { raw meat? }\end{array}$} & Wiping it out with a dish rag & $14(5.4)$ \\
\hline & Washing with soap water & $154(59.7)$ \\
\hline & Rinsing it well with water & $64(24.8)$ \\
\hline & *Washing with bleach and water & $26(10.1)$ \\
\hline
\end{tabular}

*Indicates correct answer 
Table 4. Chi-square tests on food safety knowledge and gender

\begin{tabular}{|c|c|c|c|c|}
\hline Variables & & Male (Cluster 1) & Female (Cluster 2) & $p$ value \\
\hline \multirow{4}{*}{$\begin{array}{l}\text { Temperature in the } \\
\text { refrigerator } \\
\text { should be; }\end{array}$} & $10^{\circ} \mathrm{C}$ & $9(9.0 \%)$ & $10(6.3 \%)$ & \multirow{4}{*}{0.106} \\
\hline & $2-8^{\circ} \mathrm{C}$ & $41(41.0 \%)$ & $68(43.0 \%)$ & \\
\hline & $-18^{\circ} \mathrm{C}$ & $36(36.0 \%)$ & $41(25.9 \%)$ & \\
\hline & I don't know & $14(14.0 \%)$ & $39(24.7 \%)$ & \\
\hline \multirow{4}{*}{$\begin{array}{l}\text { Growth of food } \\
\text { bacteria at body's } \\
\text { temperature }\left(37^{\circ} \mathrm{C}\right)\end{array}$} & Die & $11((11.0 \%)$ & $20(12.7 \%)$ & \multirow{4}{*}{0.421} \\
\hline & No growth & $38(38.0 \%)$ & $48(30.4 \%)$ & \\
\hline & Grow quickly & $37(37.0 \%)$ & $57(36.1 \%)$ & \\
\hline & Grow slowly & $14(14.0 \%)$ & $33(20.9 \%)$ & \\
\hline \multirow{4}{*}{$\begin{array}{l}\text { Factor that } \\
\text { encourages } \\
\text { multiplication of } \\
\text { bacteria }\end{array}$} & Refrigeration & $15(15.0 \%)$ & $14(8.9 \%)$ & \multirow{4}{*}{0.251} \\
\hline & Room Temperature & $68(68.0 \%)$ & $104(65.8 \%)$ & \\
\hline & Sterilization \& pasteurization & $8(8.0 \%)$ & $17(10.8 \%)$ & \\
\hline & I don't know & $9(9.0 \%)$ & $23(14.6 \%)$ & \\
\hline \multirow{4}{*}{$\begin{array}{l}\text { Reason to separate } \\
\text { raw and cooked food }\end{array}$} & There will be spoilage of food & $28(28.0 \%)$ & $29(18.4 \%)$ & \multirow{4}{*}{0.269} \\
\hline & The flavour will be affected & $13(13.0 \%)$ & $19(12.0 \%)$ & \\
\hline & Bacteria will transfer from raw to cooked food & $54(54.0 \%)$ & $103(65.2 \%)$ & \\
\hline & I don't know & $5(5.0 \%)$ & $7(4.4 \%)$ & \\
\hline \multirow{3}{*}{$\begin{array}{l}\text { Placing raw meat in } \\
\text { the plastic bag }\end{array}$} & Increases your chance for food borne illness & $20(20.0 \%)$ & $27(17.1 \%)$ & \multirow{3}{*}{0.723} \\
\hline & Decreases your chance for food borne illness & $59(59.0 \%)$ & $101(63.9 \%)$ & \\
\hline & Makes no difference in food borne illness & $21(21.0 \%)$ & $30(19.0 \%)$ & \\
\hline \multirow{4}{*}{$\begin{array}{l}\text { Common symptoms } \\
\text { of foodborne disease }\end{array}$} & Headache & $12(12.0 \%)$ & $8(5.1 \%)$ & \multirow{4}{*}{0.076} \\
\hline & Diarrhea & $79(79.0 \%)$ & $130(82.3 \%)$ & \\
\hline & Skin rashes & $3(3.0 \%)$ & $13(8.2 \%)$ & \\
\hline & I don't know & $6(6.0 \%)$ & $7(4.4 \%)$ & \\
\hline \multirow{4}{*}{$\begin{array}{l}\text { Best way to clean a } \\
\text { cutting board after } \\
\text { used for raw meat }\end{array}$} & Wiping it out with the dish rag & $8(8.0 \%)$ & $6(3.8 \%)$ & \multirow{4}{*}{$0.030^{*}$} \\
\hline & Washing with soap water & $59(59.0 \%)$ & $95(60.1 \%)$ & \\
\hline & Rinsing it well with water & $18(18.0 \%)$ & $46(29.1 \%)$ & \\
\hline & Washing with bleach and water & $15(15.0 \%)$ & $11(7.0 \%)$ & \\
\hline Total & & $100(38.8 \%)$ & $158(61.2 \%)$ & \\
\hline
\end{tabular}

$*(\mathrm{p}<0.05)$

higher knowledge of food poisoning compared to men (Sanlier, 2009; Akabanda et al., 2017; Zeeshan et al., 2017). According to research done by Carbas et al. (2012), women had a much accurate knowledge on preventing cross contamination when preparing or cooking food. Food mishandling was thought to be more serious among young male adults with an education level beyond high school compared to other groups. Majority of the respondents answered correctly except for the last question in which male respondents had better knowledge on the right way to clean the cutting board after using for raw meat compared to female respondents.

A Chi-square test for independence indicated no significant differences between education and the food poisoning knowledge $(\mathrm{p}>0.05)$ except for the first and third question which had a significant difference with education $(\mathrm{p}<0.05)$. From Table 5, generally, respondents who had tertiary education level had better food poisoning knowledge compared to the lower education level respondents. Studies had shown those with tertiary education had a better grasp of food poisoning knowledge compared to those with lower education (Sanlier, 2009). Being tertiary educated, consumers may expose to proper food handling, better personal hygiene and proper storage facilities. A recent meta-analysis reported that training in food safety could increase knowledge and improves attitudes about hand hygiene practices and emphasize on the positive effect of hand washing before eating meals (Pichler et al., 2013). Awareness programs can be done at schools and universities to emphasize proper food safety practices so that people would be better equipped with food safety knowledge in order to decrease the risk of foodborne illness. Knowledge empowers and recognition of personal responsibility could increase food safety awareness (Aluko et al., 2013).

For future studies, it is recommended to investigate the consumers' actual food handling practices to understand whether consumers' understanding of food safety corresponds to their food safety practices. Garayoa et al. (2005) stated that there was a considerable difference between knowledge and behavior of their respondents, as well as stated by Lee et al. (2016) in which perceived knowledge failed to be translated into practices. Understanding the baseline knowledge and actual behaviours in a target group are essential to facilitate the development of effective health education programmes. Consumers could also benefit from food safety education and information (Altekruse et al., 1999; 
Table 5. Chi-square tests on food safety knowledge and education level

\begin{tabular}{|c|c|c|c|c|}
\hline & Variables & $\begin{array}{c}\text { Lower Education } \\
(\text { Cluster } 1)\end{array}$ & $\begin{array}{c}\text { Tertiary Education } \\
\text { (Cluster 2) }\end{array}$ & $p$ value \\
\hline \multirow{4}{*}{$\begin{array}{l}\text { Temperature in the } \\
\text { refrigerator } \\
\text { should be; }\end{array}$} & $10^{\circ} \mathrm{C}$ & $8(7.0 \%)$ & $11(7.7 \%)$ & \multirow{4}{*}{$0.046^{*}$} \\
\hline & $2-8^{\circ} \mathrm{C}$ & $39((33.9 \%)$ & $70(49.0 \%)$ & \\
\hline & $-18^{\circ} \mathrm{C}$ & $37(32.2 \%)$ & $40(28.0 \%)$ & \\
\hline & I don't know & $31(27.0 \%)$ & $22(15.4 \%)$ & \\
\hline \multirow{4}{*}{$\begin{array}{l}\text { Growth of food } \\
\text { bacteria at body's } \\
\text { temperature }\left(37^{\circ} \mathrm{C}\right)\end{array}$} & Die & $17(14.8 \%)$ & $14(9.8 \%)$ & \multirow{4}{*}{0.531} \\
\hline & No growth & $37(32.2 \%)$ & $49(34.3 \%)$ & \\
\hline & Grow quickly & $43(37.4 \%)$ & $51(35.7 \%)$ & \\
\hline & Grow slowly & $18(15.7 \%)$ & $29(20.3 \%)$ & \\
\hline \multirow{4}{*}{$\begin{array}{l}\text { Factor that } \\
\text { encourages } \\
\text { multiplication of } \\
\text { bacteria }\end{array}$} & Refrigeration & $21(18.3 \%)$ & $8(5.6 \%)$ & \multirow{4}{*}{$0.009 *$} \\
\hline & Room Temperature & $67(58.3 \%)$ & $105(73.4 \%)$ & \\
\hline & Sterilization \& pasteurization & $11(9.6 \%)$ & $14(9.8 \%)$ & \\
\hline & I don't know & $16(13.9 \%)$ & $16(11.2 \%)$ & \\
\hline \multirow{4}{*}{$\begin{array}{l}\text { Reason to separate } \\
\text { raw and cooked } \\
\text { food }\end{array}$} & There will be spoilage of food & $29(25.2 \%)$ & $27(19.6 \%)$ & \multirow{4}{*}{0.239} \\
\hline & The flavour will be affected & $14(12.2 \%)$ & $18(12.6 \%)$ & \\
\hline & Bacteria will transfer from raw to cooked food & $64(55.7 \%)$ & $93(65.0)$ & \\
\hline & I don’t know & $8(7.0 \%)$ & $4(2.8 \%)$ & \\
\hline \multirow{3}{*}{$\begin{array}{l}\text { Placing raw meat } \\
\text { in the plastic bag }\end{array}$} & Increases your chance for food borne illness & $27(23.5 \%)$ & $20(14.0 \%)$ & \multirow{3}{*}{$0.045^{*}$} \\
\hline & Decreases your chance for food borne illness & $62(53.9 \%)$ & $98(68.5 \%)$ & \\
\hline & Makes no difference in food borne illness & $26(22.6 \%)$ & $25(17.5 \%)$ & \\
\hline \multirow{4}{*}{$\begin{array}{l}\text { Common } \\
\text { symptoms of } \\
\text { foodborne disease }\end{array}$} & Headache & $11(9.6 \%)$ & $9(6.3 \%)$ & \multirow{4}{*}{0.376} \\
\hline & Diarrhea & $88(76.5 \%)$ & $121(84.6 \%)$ & \\
\hline & Skin rashes & $8(7.0 \%)$ & $8(5.6 \%)$ & \\
\hline & I don't know & $8(7.0 \%)$ & $5(3.5 \%)$ & \\
\hline \multirow{4}{*}{$\begin{array}{l}\text { Best way to clean a } \\
\text { cutting board after } \\
\text { used for raw meat }\end{array}$} & Wiping it out with the dish rag & $8(7.0 \%)$ & $6(4.2 \%)$ & \multirow{4}{*}{0.736} \\
\hline & Washing with soap water & $66(57.4 \%)$ & $88(61.5 \%)$ & \\
\hline & Rinsing it well with water & $30(26.1 \%)$ & $34(23.8 \%)$ & \\
\hline & Washing with bleach and water & $11(9.6 \%)$ & $15(10.5 \%)$ & \\
\hline Total & & $115(44.6 \%)$ & $143(55.4 \%)$ & \\
\hline
\end{tabular}

$*(\mathrm{p}<0.05)$

Bruhn and Schutz, 1999). In addition, it is also valuable to investigate the association between food safety knowledge across age, income level, and other factors.

There were some limitations to this study. The data were collected using a convenience sampling approach which decreased the external validity of the results. The sampling area of the respondents was limited to only a small part of the Klang Valley, Kuala Lumpur, Malaysia. Thus, future studies should consider using a broader and systematic design to better represent the population.

\section{Conclusion}

From this study, it can be concluded that the major motivation for consumers to purchase RTE foods was due to convenience, and consumers seem to be less price -sensitive. RTE food marketers could use this data to help them understand consumer behaviour towards RTE meals. It would be beneficial to conduct further measures on a national basis, such as research to include smaller towns and rural areas, with a bigger sample size to reflect the demographic composition of Malaysia. Other factors such as cultural factors, social factors, and psychological factors should also be considered in determining consumers' behaviour.

This study also examined consumers' food safety knowledge. Generally, consumers had adequately good food safety knowledge. It is recommended to assess the relationship between food safety knowledge across age and income level. It would be valuable to investigate the consumers' actual food handling practices, to have an insight on whether consumers' understanding of food safety corresponds to their food hygiene practices. Identifying the baseline knowledge and actual behaviours in a target group could facilitate the development of more effective health education programmes.

\section{Conflict of interest}

The authors declare no conflict of interest.

\section{Acknowledgement}

This study was supported by UCSI University, Kuala Lumpur. The authors would also like to thank the consumers who participated in the study. 


\section{References}

Akabanda, F., Hlortsi, E.H. and Ousu-Kwarteng, J. (2017). Food safety knowledge, attitudes and practices of institutional food-handlers in Ghana. BMC Public Health, 2017, 17(40), 1-9. https:// doi.org/10.1186/s12889-016-3986-9

Altekruse, S.F., Yang, S., Timbo, B.B. and Angulo, F J. (1999). A multi-state survey of consumer foodhandling and food-consumption practices. American Journal of Preventive Medicine, 16(3), 216-221. https://doi.org/10.1016/S0749-3797(98)00099-3

Aluko, O.O, Ojeremi, T.T., Olakeke, D.A. and Ajidagba, E.B. (2013). Evaluation of food safety and sanitary practices among food vendors at car parks in Keife, Southwestern Nigeria. Food Control, 40, 165-171. https://doi.org/10.1016/j.foodcont.2013.11.049

Bae, H.J., Chae, M.J. and Ryu, K. (2010). Consumer behaviors towards ready-to-eat foods based on foodrelated lifestyles in Korea. Nutrition Research and Practice, 4(4), 332-338. https://doi.org/10.4162/ nrp.2010.4.4.332

Baskaran, S., Ayob, S.A., Howe, N.C. and Mahadi, N. (2017). Understanding purchase intention of ready-to -eat food among Malaysian urbanites: a proposed framework. International Journal of Academic Research in Business and Social Sciences, 7(11), 566 -579. https://doi.org/10.6007/IJARBSS/v7-i11/3496

Bruhn, C.M. and Schutz, H.G. (1999). Consumer food safety knowledge and practices. Journal of Food Safety, 19(1), 73-87. https://doi.org/10.1111/j.17454565.1999.tb00235.x

Brunner, T.A., Horst, V.D.K. and Siegrist, M. (2010). Convenience food products. Drivers for consumption. Appetite, 55(3), 498-506. https:// doi.org/10.1016/j.appet.2010.08.017

Carbas, B., Cardoso, L. and Coelho, A. (2013). Investigation on the knowledge associated with foodborne diseases in consumers of Northeastern Portugal. Food Control, 30(1), 54-57. https:// doi.org/10.1016/j.foodcont.2012.06.028

Candel, M.J. (2001). Consumer's convenience orientation towards meal preparation: Conceptualisation and measurement. Appetite, 36(1), 15-28. https://doi.org/10.1006/appe.2000.0364

Chae, M.J., Bae, H.J. and Yoon, J.Y. (2008). Consumption practices and selection attributes of the university students on ready-to-eat foods. Korean Journal of Food Service Management, 11, 289-307.

Feltes, M.M.C., Arisseto-Bragotto, A.P. and Block, J.M. (2017). Food quality, food-borne diseases, and food safety in the Brazillian food industry. Food Quality and Safety, 1(1), 13-27. https://doi.org/10.1093/fqs/ fyx003

Fotopoulos, C., Krystallis, A., Vassallo, M. and Pagiaslis, A. (2009). Food choice questionnaire (FCQ) revisited. Suggestions for the development of an enhanced general food motivation model. Appetite, 52(1), 199-208. https://doi.org/10.1016/ j.appet.2008.09.014

Garayoa, R., Córdoba, M., García-Jalón, I., SanchezVillegas, A. and Vitas, A.I. (2005). Journal of Food Protection, 16(12), 2631-2636. https:// doi.org/10.4315/0362-028X-68.12.2631

Geeroms, N., Verbeke, W. and Kenhove, V.P. (2008). Consumers health-related motive orientation and ready meal consumption behavior. Appetite, 51(3), 704-712. https://doi.org/10.4315/0362-028X68.12 .2631

Heroux, M., Iannotti, R.J., Currie, D., Pickett, W. and Janssen, I. (2012). The food retail environment in school neighborhoods and its relation to lunchtime eating behaviors in youth from three countries. Health Place, 18(6), 1240-1247. https:// doi.org/10.1016/j.healthplace.2012.09.004

Kennedy, J., Jackson, V., Cowan, C., Blair, I., McDowell, D. and Bolton, D. (2005). Consumer food safety knowledge. Segmentation of Irish home food preparers based on food safety knowledge and practice. British Food Journal, 107(7), 441-452. https://doi.org/10.1108/00070700510606864

Lee, H.K., Halim, H.A., Thong, K.L. and Chai, L.C. (2016). Assessment of food safety knowledge, attitude, self-reported practices, and microbiological hand hygiene of food handlers. International Journal of Environmental Research and Public Health, 14 (55), 1-14. https://doi.org/10.3390/ijerph14010055

Maysenburg, R., Albecht, J.A., Litchfield, R. and RitterGooder, P.K. (2014). Food safety knowledge, practices and beliefs of primary food preparers in families with young children. A mixed methods study. Appetite, 73, 121-131. https://doi.org/10.1016/ j.appet.2013.10.015

Muniady, R., Mamun, A.A., Permarupan, P.Y. and Zainol, N.R. (2014). Factors influencing consumer behavior: A study among university students in Malaysia. Asian Social Science, 10(9), 18-25. https:// doi.org/10.5539/ass.v10n9p18

Olsen, N.V., Sijtsema, S.J. and Hall, G. (2010). Predicting consumers' intention to consume ready-to -eat meals. The role of moral attitude. Appetite, 55 (3), 534-539. https://doi.org/10.1016/ j.appet.2010.08.016

Pichler, J., Ziegler, J., Aldrian, U. and Allerberger, F. (2013). Evaluating levels of knowledge on food 
safety among food handlers from restaurants and various catering businesses in Vienna, Austria, 20112012. Food Control Journal, 35(1), 33-40. https:// doi.org/10.1016/j.foodcont.2013.06.034

Priyadarshini, V. (2015). Purchasing practice of the consumers towards ready-to-eat food products. Asian Journal of Home Science, 10(2), 290-295. https:// doi.org/10.15740/HAS/AJHS/10.2/290-295

Sanlier, N. (2009). The practice of food safety by young and adult consumers. Journal of Food Control, 20 (6), $538-542 . \quad$ https://doi.org/10.1016/ j.foodcont.2008.08.006

Scholliers, P. (2015). Convenience foods. What, why, and when. Appetite, 94, 2-6. https://doi.org/10.1016/ j.appet.2015.02.017

U.S. Food and Drug Administration (USFDA) (2017). Food Code 2017, p. 1 - 57. College Park, USA. United States Public Health Service, Food and Drug Administration.

Woh, P.Y., Thong, K.L., Behnke, J.M., Lewis, J.W. and Zain, S.N.M. (2016). Evaluation of basic knowledge on food safety and food handling practices amongst migrant food handlers in Peninsular Malaysia. Food Control, 70, 64-73. https://doi.org/10.1016/ j.foodcont.2016.05.033

World Health Organization (WHO). (2019). Food safety. Retrieved on July 20, 2019 from HO website: https:// www.who.int/news-room/factsheets/detail/

foodsafety\#targetText=An\%20estimated $\% \quad 20600 \%$ 20million\%20\%E2\% 80\%93\%20almost,healthy\% 201ife\%20years\%20(DALYs)

Zeeshan, M., Shah, H., Durrani, Y., Ayub, M., Jan, Z. and Shah, M. (2017). A questionnaire-based survey on food safety knowledge during food-handling and food preparation practices among university students. Journal of Clinical Nutrition and Dietetics, 3(2), 1-8. https://doi.org/10.4172/2472-1921.100052 